\title{
Protecting the environment through insect farming as a means to produce protein for use as livestock, poultry, and aquaculture feed
}

\author{
J.K. Tomberlin 1", A. van Huis ${ }^{2}$, M.E. Benbow ${ }^{3}$, H. Jordan ${ }^{4}$, D.A. Astuti ${ }^{5}$, D. Azzollini ${ }^{6}$, I. Banks ${ }^{7}$, V. Bava ${ }^{8}$, \\ C. Borgemeister ${ }^{9}$, J.A. Cammack ${ }^{1}$, R.S. Chapkin ${ }^{1}$, H. Čičková ${ }^{10}$, T.L. Crippen ${ }^{11}$, A. Day ${ }^{12}$, M. Dicke ${ }^{2}$, D.J.W. Drew ${ }^{13}$, \\ C. Emhart ${ }^{14}$, M. Epstein ${ }^{15}$, M. Finke ${ }^{16}$, C.H. Fischer ${ }^{17}$, D. Gatlin ${ }^{1}$, N.Th. Grabowski ${ }^{18}$, C. He ${ }^{19}$, L. Heckman ${ }^{20}$, \\ A. Hubert ${ }^{21}$, J. Jacobs ${ }^{22}$, J. Josephs ${ }^{23}$, S.K. Khanal ${ }^{24}$, J.-F. Kleinfinger ${ }^{25}$, G. Klein ${ }^{18}$, C. Leach ${ }^{26}$, Y. Liu ${ }^{27}$, G.L. Newton ${ }^{28}$, \\ R. Olivier ${ }^{29}$, J.L. Pechal ${ }^{30}$, C.J. Picard ${ }^{31}$, S. Rojo ${ }^{32}$, A. Roncarati ${ }^{33}$, C. Sheppard ${ }^{34}$, A.M. Tarone ${ }^{1}$, B. Verstappen ${ }^{35}$, \\ A. Vickerson ${ }^{36}$, H. Yang ${ }^{37}$, A.L. Yen ${ }^{38,39}$, Z. Yu ${ }^{40}$, J. Zhang ${ }^{40}$ and L. Zheng ${ }^{40}$
}

${ }^{1}$ Texas AEM University, Department of Entomology, 2475 TAMU, College Station, TX 77843, USA; ${ }^{2}$ Wageningen University, Department of Plant Sciences, Laboratory of Entomology, P.O. Box 16, 6700 AA Wageningen, the Netherlands; ${ }^{3}$ Michigan State University, Department of Entomology and Department of Osteopathic Medical Specialties, 243 Natural Science Building, Lansing, MI 48824, USA; ${ }^{4}$ Mississippi State University, Department of Biological Sciences, P.O. Box GY, Mississippi State, MS 39762, USA; ${ }^{5}$ Bogor Agricultural University, Department of Nutrition and Feed technology, Agathis Kampus IPB Darmaga, Bogor, West Java, 16680, Indonesia; ${ }^{6}$ University of Foggia, Department of Science of Agriculture, Food and Environment, Via Napoli 25, Foggia 71121, Italy; ${ }^{7}$ AgriProtein Technologies, Research and Development, 1 Rochester Road, cnr Stock Road, Philippi, Cape Town, Western Cape, 7781, South Africa; ${ }^{8}$ Diptera s.r.l., S.P. 141, km 7,200, Manfredonia 71043, Italy; ${ }^{9}$ University of Bonn, Centre for Development Research, Walter-Flex-Str. 3, 53113 Bonn, Germany; ${ }^{10}$ Institute of Zoology, Slovak Academy of Sciences, Dúbravská cesta 9, Bratislava 845 06, Slovakia; ${ }^{11}$ Agricultural Research Service, SPARC, 2881 FEB Road College Station, TX 77845, USA; ${ }^{12} 4$ Ento Sarl, Chemin des Ramiers 12, Pully-Vaud 1009, Switzerland; ${ }^{13}$ AgriProtein, 33 Church Street, Cape Town 8001, South Africa; ${ }^{14}$ F4F, Camino La Fuente 1558, Las Condes, Santiago, Región Metropolitana, 7591293, Chile; ${ }^{15}$ Medical Univeristy of Vienna, Department of Dermatology, Waehringer Guertel 18-20, Vienna 1090, Austria; ${ }^{16}$ Mark Finke LLC, 17028 Wildcat Drive, Rio Verde, AZ 85263, USA; ${ }^{17}$ Danish Technological Institute, Chemistry and Biotechnology, Kongsvang Alle 29, Aarhus C 8000, Denmark; ${ }^{18}$ Stiftung Tierärztliche Hochschule, Hannover University of Veterinary Medicine, Foundation, Institut für Lebensmittelqualität und -sicherheit, Institut for Food Quality and Food Safety, LMQS, Bischofsholer Damm 15, 30173 Hannover, Germany; ${ }^{19}$ Wuhan Chaotuo Ecological Agriculture Co., LTD, Shanpo street, Jiangxia District, Wuhan, Hubei Province, 430216, China P.R.; ${ }^{20}$ Danish Technological Institute, Chemistry and Biotechnology, Kongsvang Alle 29, Aarhus C 8000, Denmark; ${ }^{21}$ International Platform of Insect for Food and Feed, Rue Belliard 199, B.22, 1040 Brussels, Belgium; ${ }^{22}$ Millibeter, Dambruggestraat 200, 2060 Antwerpen, Belgium; ${ }^{23}$ The Bug Shack, 50 Harland Road, Bournemouth BH6 4DW, United Kingdom; ${ }^{24}$ University of Hawaii at Manoa, Molecular Biosciences and Bioengineering, 1955 East-Wedt Rd., Ag. Sci. 218, Honolulu, HI 96822, USA; ${ }^{25}$ NextAlim, 2 Avenue Galilée, Futuroscope, 86961 Chasseneuil-du-Poitou cedex, France; ${ }^{26}$ Midas Meal, 235 Nicholson St., Abbotsford, VIC, 3067, Australia; ${ }^{27}$ Shandong Agricultural University, College of Plant Protection, No. 61, Daizong Street, Taian, Shandong Province, 271000, China P.R.; ${ }^{28}$ University of Georgia Tifton Campus, Animal \& Dairy Science Dept., 4251 US Hwy 319 S, Tifton, GA 31793, USA; ${ }^{29}$ Prota Culture, LLC, P.O. Box 4120 \#15135, Portland, OR 97208-4120, USA; ${ }^{30}$ Michigan State University, Department of Entomology, 243 Natural Science Building, Lansing, MI 48824, USA; ${ }^{31}$ Indiana University Purdue University Indianapolis (IUPUI), Department of Biology, 723 W. Michigan Street, Indianapolis, IN 46202, USA; ${ }^{32}$ University of Alicante, Department of Environmental Sciences and Natural Resources, P.O. Box 99, 03080 Alicante, Spain; ${ }^{33}$ University of Camerino, School of Biosciences and Veterinary Medicine, Viale Circonvallazione 93/95, 62024 Matelica, Italy; ${ }^{34}$ Insect Science Resource LLC, 768 Brighton Road Tifton, GA 31794, USA; ${ }^{35}$ Eawag - ETH Zurich, Sandec (Sanitation, Water and Solid Waste for Development), Ueberlandstrasse 133, 8600 Duebendorf, Switzerland; ${ }^{36}$ Enterra Feed Corporation, Research and Development, 134 Great Northern Way, Vancouver, BC, V5T4T5, Canada; ${ }^{37}$ Central China Normal University, School of Life Sciences, 152 Luoyu Avenue, Wuhan, Hubei Province, 430079, China P.R.; ${ }^{38}$ Biosciences Research Branch, Department of Economic Development, Jobs, Transport \& Resources, AgriBio, 5 Ring Road, La Trobe University, Bundoora, Victoria 3083, Australia; ${ }^{39}$ School of Applied Systems Biology, La Trobe University, AgriBio, 5 Ring Road, Bundoora, Victoria 3083, Australia; ${ }^{40}$ Huazhong Agricultural University, College of Life Science and Technology, No. 1, Shizishan Street, Wuhan, Hubei Province, 430070, China P.R.; jktomberlin@tamu.edu

Received: 11 November 2015 / Accepted: 16 November 2015

(c) 2015 Wageningen Academic Publishers 


\title{
OPINION ARTICLE
}

\begin{abstract}
Securing protein for the approximate 10 billion humans expected to inhabit our planet by 2050 is a major priority for the global community. Evidence has accrued over the past 30 years that strongly supports and justifies the sustainable use of insects as a means to produce protein products as feed for pets, livestock, poultry, and aquacultured species. Researchers and entrepreneurs affiliated with universities and industries, respectively, from 18 nations distributed across North and South America, Europe, Asia, Africa and Australia contributed to the development of this article, which is an indication of the global interest on this topic. A brief overview of insects as feed for the aquaculture industry along with a review of the black soldier fly, Hermetia illucens (Diptera: Stratiomyidae), as a model for such systems is provided.
\end{abstract}

Keywords: conservation, Hermetia illucens, sustainable agriculture, waste management

Securing resources to provide protein needed to sustain the projected human population is a top priority of most governments (Godfray et al., 2010). Estimated population growth from 2005 to 2050 indicates global food demand to increase by $100 \%$ (Tilman et al., 2011), while agricultural production is projected to increase only by $60 \%$ (FAO, $2014 b)$. The increase of global production of specific agricultural commodities will fall substantially short of what is needed to meet projected demands in 2050 (shortages of approximately $67,42,38$, and $55 \%$, for maize, rice, wheat and soybean, respectively) (Ray et al., 2013). The global inability to sustain the necessary food production will emanate in increased duress of approximately 805 million undernourished people living in developing countries (FAO, 2014b; FAO et al., 2012), which could lead to greater risk of local, national and global disease (Kau et al., 2011).

Increasing crop production only represents a short-term solution and has been anticipated to negatively impact the environment on a large scale. For instance, nitrogen and phosphorus use is expected to increase by $40-50 \%$ due to increases in crop production, which will impact water quality (coastal and fresh water, fish kills), air quality (pollutants such as $\mathrm{NH}_{3}$ and $\mathrm{NO}_{2}$ ), soil degradation (loss of fertility and erosion), degradation of ecosystems (e.g. eutrophication), and biodiversity (loss of species) (Sutton et al., 2013; Tilman, 1999). Greenhouse gas emissions from agriculture, forestry and other land use activities could increase $30 \%$ by 2050 (FAO, 2014a). To hold the increase in global temperature below two degrees Celsius and avoid 'dangerous' climate change, deep cuts in global emissions are urgently required (Gerber et al., 2013).

Aquaculture is the fastest-growing animal food-producing sector globally (Subasinghe et al., 2009) where production from both aquaculture and wild-capture will exceed that of beef, pork or poultry within the next decade alone (FAO, 2012). Fish are harvested from international waters to produce fishmeal, which is used as feed in the aquaculture and livestock industry. In 2010, aquaculture utilised 73\% of fishmeal and 71\% of fish oil produced (FAO, 2014b). However, international fisheries are being over-exploited and current practices are not sustainable, which is evident as current production of fishmeal and fish oil has decreased from 30.2 million tons (live weight) in 1994 to 16.3 tons in 2012 (FAO, 2014b). Alternate sources of protein are therefore urgently needed to sustain the aquaculture industry.

The black soldier fly Hermetia illucens (Diptera: Stratiomyidae) represents one example of insect species such as housefly, mealworm and cricket that can be used for producing protein for use as livestock and fish feed and human food with minimum negative environmental impact and human health effects. This insect is able to convert organic by-products, such as food waste $(\sim 1.3$ billion tons produced globally on an annual basis), which is an under-utilised sustainable resource (FAO, 2011) valued at 750 billion US\$ (The Economist, 2014). This insect, like many others, can also be used to recycle livestock waste, which is a concern for pollution as well (Diener et al., 2015; Sheppard et al., 1994). It transforms 50\% dry matter of these organic side streams into insect biomass with a high protein value (Sheppard et al., 1994). This insect is not a pest and is known to suppress pathogens of people and livestock. Furthermore, tons of this insect can be potentially produced daily in limited space using large industrial facilities. But it can also be produced by nonmechanised harvesting, which is important in developing nations of the world that rely heavily on human labour and have limited technological resources. We also know that the black soldier fly can successfully replace approximately $50 \%$ of the fishmeal used to produce rainbow trout (St. Hilaire et al., 2007), and is a suitable replacement feed for a number of aquacultured species such as catfish, tilapia (Bondari and Sheppard, 1987) and salmon (Lock et al., in press), and - outside of aquaculture - chickens (Hale, 1973) and swine (Newton et al., 1977). Presently, resources 
are needed through government agencies to conduct the necessary research to address concerns over food safety, optimal production, and utilisation of protein resulting from insect farming.

We hope that other scientists, policy makers, government officials and food production representatives will consider joining us through discussions on how to create opportunities to conduct research on this topic as to provide appropriate information to our legislators, and create momentum resulting in a cultural shift leading to legislative changes allowing for the use of such a promising sustainable resource to be explored and ultimately implemented. Application of insect farming for protein production would facilitate a means of supplying the materials needed for the production of pet, livestock, poultry and aquaculture feed and human food. In turn, such resources will allow us to face the challenges of the rapidly growing global human population. Insects as feed and food have great promise as a new agricultural sector, but there is an urgent need of a political and regulatory environment conducive for their use.

\section{References}

Bondari, K. and Sheppard, D.C., 1987. Soldier fly Hermetia illucens L., as feed for channel catfish, Ictalurus punctatus (Rafinesque), and blue tilapia, Oreochromis aureus (Steindachner). Aquaculture and Fisheries Management 18: 209-220.

Diener, S., Zurbrügg, C. and Tockner, K., 2015. Bioaccumulation of heavy metals in the black soldier fly, Hermetia illucens and effects on its life cycle. Journal of Insects as Food and Feed 1: 261-270.

Food and Agriculture Organization of the United Nations (FAO), 2011. Global food losses and food waste - Extent, causes and prevention. FAO, Rome, Italy. Available at: http://www.fao.org/docrep/014/ mb060e/mb060e.pdf.

Food and Agriculture Organization of the United Nations (FAO), 2012. The state of world fisheries and aquaculture 2012. FAO, Rome, Italy. Available at: http://www.fao.org/docrep/016/i2727e/i2727e.pdf.

Food and Agriculture Organization of the United Nations (FAO), 2014a. Agriculture, forestry, and other land use emissions by sources and removal by sinks. FAO, Rome, Italy. Available at: http://www. fao.org/docrep/019/i3671e/i3671e.pdf.

Food and Agriculture Organization of the United Nations (FAO), 2014b. The state of world fisheries and aquaculture. FAO, Rome, Italy. Available at: http://www.fao.org/fishery/sofia/en.

Food and Agriculture Organization of the United Nations (FAO), World Food Programme (WFP) and International Fund for Agricultural Development (IFAD), 2012. The state of food insecurity in the world. Economic growth is necessary but not sufficient to accelerate reduction of hunger and malnutrition. FAO, Rome, Italy. Available at: http://www.fao.org/docrep/016/i3027e/i3027e.pdf.

Gerber, P.J., Steinfeld, H., Henderson, B., Mottet, A., Opio, C., Dijkman, J., Falcucci, A. and Tempio, G., 2013. Tackling climate change through livestock - A global assessment of emissions and mitigation opportunities. Food and Agriculture Organization of the United Nations, Rome, Italy. Available at: http://www.fao.org/3/i3437e.pdf.
Godfray, H.C.J., Beddington, J.R., Crute, I.R., Haddad, L., Lawrence, D., Muir, J.F., Pretty, J., Robinson, S., Thomas, S.M. and Toulmin, C., 2010. Food security: the challenge of feeding 9 billion people. Science 327: 812-818.

Hale, O.M., 1973. Dried Hermetia illucens larvae (Stratiomyidae) as a feed additive for poultry. Journal of the Georgia Entomological Society 8: 16-20.

Kau, A.L., Ahern, P.P., Griffin, N.W., Goodman, A.L. and Gordon, J.I., 2011. Human nutrition, the gut microbiome and the immune system. Nature 474: 327-336.

Lock, E.R., Arsiwalla, T. and Waagbø, R., in press. Insect larvae meal as an alternative source of nutrients in the diet of Atlantic salmon (Salmo salar) postsmolt. Aquaculture Nutrition, DOI: http://dx.doi. org/10.1111/anu.12343.

Newton, G.L., Booram, C.V., Barker, R.W. and Hale, O.M., 1977. Dried Hermetia illucens larvae meal as a supplement for swine. Journal of Animal Science 44: 395-400.

Ray, D.K., Mueller, N.D., West, P.C. and Foley, J.A., 2013. Yield trends are insufficient to double global crop production by 2050. PLoS ONE 8: e66428.

Sheppard, D.C., Newton, G.L., Thompson, S.A. and Savage, S., 1994. A value added manure management system using the black soldier fly. Bioresource Technology 50: 275-279.

St. Hilaire, S., Sheppard, C., Tomberlin, J.K., Irving, S., McGuire, M.A., Mosley, E.E., Hardy, R.W. and Sealey, W., 2007. Fly prepupae as a feedstuff for rainbow trout, Oncorhynchus mykiss. Journal of the World Aquaculture Society 38: 59-67.

Subasinghe, R., Soto, D. and Jia, J., 2009. Global aquaculture and its role in sustainable development. Reviews in Aquaculture 1: 2-9.

Sutton, M.A., Bleeker, A., Howard, C.M., Bekunda, M., Grizzetti, B., De Vries, W., Van Grinsven, H.J.M., Abrol, Y.P., Adhya, T.K., Billen, G., Davidson, E.A., Datta, A., Diaz, R., Erisman, J.W., Liu, X.J., Oenema, O., Palm, C., Raghuram, N., Reis, S., Scholz, R.W., Sims, T., Westhoek, H. and Zhang, F.S., with contributions from Ayyappan, S., Bouwman, A.F., Bustamante, M., Fowler, D., Galloway, J.N., Gavito, M.E., Garnier, J., Greenwood, S., Hellums, D.T., Holland, M., Hoysall, C., Jaramillo, V.J., Klimont, Z., Ometto, J.P., Pathak, H., Plocq Fichelet, V., Powlson, D., Ramakrishna, K., Roy, A., Sanders, K., Sharma, C., Singh, B., Singh, U., Yan, X.Y. and Zhang, Y., 2013. Our nutrient world: the challenge to produce more food and energy with less pollution. Global overview of nutrient management. Centre for Ecology and Hydrology, Edinburgh, UK. Available at: http://www. unep.org/gpa/documents/publications/ONW.pdf.

The Economist, 2014. Food loss and its intersection with food security. Global food security index 2014: an annual measure of the state of global food security. The Economist Intelligence Unit, London, UK. Available at: http://www.economist.com.

Tilman, D., 1999. Global environmental impacts of agricultural expansion: the need for sustainable and efficient practices. Proceedings of the National Academy of Sciences 96: 5995-6000.

Tilman, D., Balzer, C., Hill, J. and Befort, B.L., 2011. Global food demand and the sustainable intensification of agriculture. Proceedings of the National Academy of Sciences 108: 20260-20264. 
